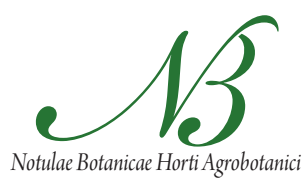

Cluj-Napoca

\title{
Total Economic Value of Natural Capital - A Case Study of Piatra Craiului National Park
}

\author{
Bogdan POPA ${ }^{1}$, Claudiu COMAN², Stelian A. BORZ*, Dan M. NITA', Codrin CODREANU', \\ Gheorghe IGNEA ${ }^{1}$, Viorel MARINESCU' ${ }^{1}$, Florin IORAS ${ }^{3}$, Ovidiu IONESCU' \\ ${ }^{1}$ Transilvania University, Faculty of Silviculture and Forest Engineering, 1 Sirul Beethoven, 500123 Brasov, \\ Romania;popab03@gmail.com; stelian.borz@unitbv.ro ("correspondingauthor);nita_mihai_daniel@yahoo. \\ com;.codreanu@unitbv.ro;igneagh@unitbv.ro;viorel.marinescu@unitbv.ro; oionescu@unitbv.ro \\ ${ }^{2}$ Transilvania University, Faculty of Sociology and Communication, 32 Eroilor Bld., 500030 Brasov, Romania; claudiu.coman@unitbv.ro \\ ${ }^{3}$ Buckinghamshire New University, Queen Alexandra Road, High Wycombe, HP 11 \\ 2JZ Buckinghamshire, United Kingdom; florin.ioras@googlemail.com
}

\begin{abstract}
In the last two decades different methodologies for assessing the economic implications of protected areas have been developed within the framework of "Total Economic Value", taking into account not only goods and services that have a price and a market but also those not priced or marketed. The present paper, by using a number of recognized methodologies applied by environmental economists around the world, estimates the economic value of ecosystem services of Piatra Craiului National Park, in one of the first attempts to frame ecosystem services valuation in Romania. The approach and results include a benefit distribution analysis, for both the economic sectors and the groups of beneficiaries. Even if the data are not comprehensive and depend on several assumptions, the paper provides very important practical and policy-relevant information on the economic value of Piatra Craiului National Park, in an attempt to stimulate increasing of the budgetary allocation and economic policy priority for protected areas in Romania.
\end{abstract}

Keywords: biodiversity, ecosystem services, non-market value, protected areas

\section{Introduction}

Although the primary goal of Protected Areas (PAs) is biodiversity and ecosystem conservation, they typically leave an important economic footprint (Emerton, 2011; MA, 2005; TEEB, 2010). The substantial values generated by biodiversity and ecosystems are distributed across many sectors and beneficiaries groups, and can be captured in monetary terms by ecosystem services (ES) valuation (TEEB, 2010).

There are four basic categories of ecosystem services: provisioning, regulating, cultural and supporting services, all of them constituents of human wellbeing (MA, 2005). In standard economics, the value of every good is defined by its market value, and the fact that many of the ecosystems are not priced or marketed (Emerton, 2011) has posed a problem to economists. Thus, over the last two decades, several methods have been developed for dealing with the economic value of ES (TEEB, 2010). The Total Economic Value (TEV) has become the most commonly used framework for identifying and categorizing ES values (Emerton, 2009). TEV framework considers not only the direct values of the provisioning services (raw materials and physical products) but also indirect values (ecological functions which maintain and protect the natural and human systems), option values (the premium placed on maintaining the ecosystems for their future possible uses) and existence values (the intrinsic value of ecosystems regardless of the current or future possibilities to use them) (Emerton, 2009). The aim of TEV framework is to determine public and private decision makers to treat PAs as economically valuable assets, and to recognize the opportunities the investment in PAs brings to the economy (Emerton, 2011; TEEB, 2010).

Romanian PAs are known for their high conservation value, with very valuable and diverse habitats, including a significant surface of old growth primary forests (Stancioiu et al., 2010; Abrudan, 2012) and one of the largest European populations of carnivores. Different studies point out that PAs management suffers from severe underfunding (Birda, 2011). This situation triggered the experts' interest for valuing ES in Romania by using TEV framework (Bann and Popa, 2012; Ceroni, 2007; Dumitras and Dragoi, 2006; Poynton et al., 2000). However, there is a general sense of need to continue the research in the field.

In the attempt to follow the above-identified needs, the aim of this paper is to create a viable frame for assessing the TEV of PAs under current Romanian data availability conditions and present PAs assets in a friendly manner for decision makers. By using different valuation techniques, the 
paper presents the TEV of ES in Piatra Craiului National Park (PCNP), generating also a distributional analysis for decision makers to assess and design proper Payments for Ecosystem Services (PES) mechanisms.

\section{Materials and methods}

PCNP is located in the Central Romanian Carpathians. The list of important protected species in the park includes the Piatra Craiului carnation (Dianthus callizonus) - symbol of the Piatra Craiului massif, Taxus baccata, Angelica arbangelica, Nigritella nigra and N. rubra, Papaver alpinum ssp. corona-sancti-stefani; Linaria alpine, Leontopodium alpinum, Trolius europaeus, Rhododendron mytifolium, Gladiolus imbricatus, Gentiana lutea, Daphne blagayana, Daphne cneorum. The massif is covered, from the bottom towards the ridge, by hay fields, forests, bare rocks and alpine meadows. PCNP also holds a significant population of large carnivores. Its management objectives are ranging from biodiversity conservation to tourism development and conservation of local tradition. Local communities from PCNP have a rich history of traditional breeding and forest harvesting. The area is considered as having a very high but untapped touristic potential (PCNP, 2008).

The approach used in this study involved firstly the identification of all ES that PCNP generates. This first step was accomplished through a series of workshops with relevant experts and the PCNP management team, which allowed a rapid assessment of data availability for choosing appropriate valuation techniques. ES identification relied on the following criteria (developed during the workshops): i) importance of ES for local livelihoods; ii) development and investments opportunities for the future; iii)importance of maintaining traditional use of land and iv) risk of ES flow diminishing due to resource exploitation pressures.

The second step entailed by the applied approach was assessing the economic values of ES, based on their impact on each economic sector. Data collection was based on statistical records of different institutions, the management plan of PCNP (PCNP, 2008), records which are routinely kept by park management, statistical and operational reports of Forest Districts in the area, Forest Management Plans (FMPs), all of them supplemented by a review of the available literature on the economic value of PAs in Romania or in the countries from the region. A range of valuation methods (Tab. 1) were adopted to estimate the market and non-market values of the ES, all approaches being well documented in the environmental economics literature (Bateman et al., 2002; Bockstael and McConnell, 2006; Kanninen, 2006; Taylor, 2003; Ward and Beal, 2000).

For agricultural and forestry provisioning services and urban water provisioning services, values were estimated by computing the market value of products. Compensation payment values (for forest owners) were calculated based on the official Government approved formula (M.O., 2006). Values for hunting and non-timber forest products (NTFPs) were transferred using benefit transfer techniques from other studies (Ceroni, 2007). Standing volumes for forest stands were estimated using standard volume calculation equations (Giurgiu et al., 1972; Leahu, 1994). The Biomass Extension Factor, the average wood density values and the corresponding coefficients for carbon concentration within wood biomass are based on IPCC guidelines (IGES, 2006). Watershed identifica-

Tab. 1. Summary of valuation methods and data used for valuation of ES

\begin{tabular}{|c|c|c|}
\hline Ecosystem service & Valuation method & Data used \\
\hline $\begin{array}{l}\text { Food/ agricultural } \\
\text { products }\end{array}$ & Market pricing & $\begin{array}{l}\text { Market price for agricultural products, support capacity of the pastures, area } \\
\text { of pasture, average overgrazing or actual overgrazing data, (PCNP, 2008) } \\
\text { milk prices/earnings (assuming that earnings are unitary based on LSU } \\
\text { (Livestock Unit) indicator for pastures and hay production areas) }\end{array}$ \\
\hline Wood and NTFPs & Market pricing, transfer benefit & $\begin{array}{l}\text { GIS database of the PA administration, forest qualitative and quantitative data, harvested } \\
\text { wood and NTFPs quantities and market prices, illegal logging values and quantities, game } \\
\text { management and NTFPs revenues under similar conditions in the region (Ceroni, 2007). }\end{array}$ \\
\hline Water & Market pricing & $\begin{array}{l}\text { Water consumption/capita/year and population paying for } \\
\text { water and price paid per cubic metre of water. }\end{array}$ \\
\hline $\begin{array}{l}\text { Climate change } \\
\text { mitigation }\end{array}$ & Market pricing & $\begin{array}{l}\text { Estimated CO2 sink, based on standing wood volumes } \\
\text { and increments, CO2e market prices. }\end{array}$ \\
\hline $\begin{array}{l}\text { Soil erosion } \\
\text { regulation }\end{array}$ & $\begin{array}{l}\text { Market pricing, Production } \\
\text { inputs, benefit transfer }\end{array}$ & $\begin{array}{l}\text { Vegetation maps (Corine Land Cover), surface, slope, soil quality (GIS } \\
\text { data base from PCNP administration and forest management plans), } \\
\text { urban water quantities used, prices for urban water, treatment costs, links } \\
\text { between water treatment costs and water quality (Forster, 1987). }\end{array}$ \\
\hline $\begin{array}{l}\text { Recreation } \\
\text { Educational } \\
\text { Spiritual, heritage }\end{array}$ & $\begin{array}{l}\text { Benefit transfer, travel cost, } \\
\text { contingent valuation }\end{array}$ & $\begin{array}{l}\text { Visitor numbers (INCDT, 2009), Visitor expenditure (Ceroni, 2007), } \\
\text { consumer surplus (Dumitras and Dragoi, 2006; Dumitras et al., 2011) }\end{array}$ \\
\hline
\end{tabular}


610

tion and mapping were based on a digital elevation model, while soil erosion was quantified using the universal soil loss equation (Terente, 2008). Water sector TEV was calculated based on water treatment cost reduction due to decreasing soil erosion leading to diminished water turbidity. The values which were the object of the benefit transfer techniques were adjusted to 2012 price levels, by applying a consumer price index deflator. Results were grouped into several beneficiaries' categories: i) public beneficiaries (public agencies and institutions), ii) private beneficiaries (private enterprises or individuals) and iii) non-commercial beneficiaries (possible beneficiaries of the untapped economic values). Taxes and other government contribution associated to ES beneficiaries were not accounted as public revenues.

\section{Results and discussion}

\section{A. The contribution of PCNP to key sectors}

\section{a. Tourism}

In 2010 only few PAs in Romania generated revenues from park entry fees, PCNP not being among them (Birda, 2011), but PCNP visitors spent money on accommodation and meals. Recent studies done in Maramures Mountains National Park (MNP) estimate that the total daily expenditure per visitor can reach €27.1 (Ceroni, 2007). Similar studies in the region prove that this estimate is rather conservative. For example in Slovensky Raj National Park, the total visitor expenditure averages $€ 54$ per person day (Getzner, 2009). In PCNP, the majority of tourists $(60 \%)$ use tents while trekking around the high altitude areas (INCDT, 2009). Based on the number of visitors multiplied by the percentage of tourists with longer stays multiplied by the total expenditure per visit, direct spending on hotels and meals was estimated to be $€ 6$ mill. (Tab. 2).

The total economic value of PAs tourism is greater than the amount of money people actually spend because some tourists would be willing to pay more than they do to enjoy the tourism experience of a PA. This "consumer surplus" is measured by a visitor's maximum willingness to pay for the PA tourism experience less their actual expenditure (Bann and Popa, 2012). The results of a study done in 2005 (Dumitras at al., 2011) to estimate the economic value of recreation in several parks in Romania, showed that the consumer surplus was $€ 44.3$ for PCNP, and consequently, the total consumer surplus equalled $€ 4.9$ million in 2012 prices.

\section{b. Forestry}

In terms of wood production, the value of forests in PCNP was $€ 0.42$ million in 2012 (Tab. 2). Compensatory payments for privately owned protection forests are influenced by the decreased percentage (40\%) of the publicly owned forests. Both private and public forest administra- tors contribute $3 \%$ of the value of standing wood sales to the National Environmental Fund (NEF). This added an additional $€ 0.01$ million to public revenues from forestry in 2012. Illegal logging is estimated at around $€ 16,056 \mathrm{ac}-$ counted to the private sector in 2012. The value for NTFPs production, based on the data provided by the study done in MNP (Ceroni, 2007) is estimated at $€ 0.09$ million in PCNP. Ceroni (2007) estimates hunting in MNP at RON 0.1 million. By using the benefit transfer techniques in a conservative manner (reducing by $25 \%$ the value corresponding to a sustainable game level), according to the Ceroni methodology (2007) the hunting value is equivalent to $€ 3,305$ for PCNP in 2012.

Tab. 2. Value for ES in PCNP per sector/activity

\begin{tabular}{|cc|}
\hline Sector/category & Value (EUR) \\
\hline & Tourism \\
\hline Direct spending on hotels and restaurants & $5,991,810$ \\
\hline Visitor consumer surplus & $4,864,200$ \\
\hline Revenues to PA administration & 0 \\
\hline Total & $10,856,010$ \\
\hline & Forestry \\
\hline Income to public forest administrators & 162,052 \\
\hline Income to private forest & 241,586 \\
\hline administrators and owners & 9,634 \\
\hline Income to NEF & 16,056 \\
\hline Income from illegal logging & 429,329 \\
\hline Total & Agriculture \\
\hline Equivalent income to animal breeders & $1,829,288$ \\
\hline & Carbon sequestration \\
\hline Additional CO2 value 2009-2010 & 128,802 \\
\hline Revenues to water operators & Water \\
\hline Total & 227,893 \\
\hline Value of soil erosion regulation services & 880 \\
\hline Total economic value & 228,773 \\
\hline
\end{tabular}

\section{c. Agriculture}

In PCNP for a total pasture area of 379 ha the carrying capacity was estimated at 260 Livestock unit (LSU) in 2000 (i.e. $1.4 \mathrm{LSU} / \mathrm{ha}$ ), while there were $566 \mathrm{LSU}$ using the pastures, resulting in an overgrazing of $218 \%$ (PCNP, 2008). Assuming that a LSU produces 15 litres of milk per day (MARD, 2011), an average producer price of RON 0.7 per litre in 2008 (MARD, 2011), and that the number of animals is more or less constant between 2007 and 2011 the derived value is $€ 1,829,297$, all accounted for private sector in 2012 . The fact that the carrying capacity is severely overpassed requests urgent measures. A sustainable economic value of the considered ecosystem service is estimated at $€ 0.8$ million. 


\section{d. Carbon sequestration}

The result for the period $2011-2012$ is 35,983 tons of additional $\mathrm{CO} 2$. The average price $(\$ 4.5 / \mathrm{tCO} 2 \mathrm{e})$ for $\mathrm{CO} 2$ reported by New Energy Finance and Ecosystem Marketplace was used to determine the potential value of those additional quantities. Thus, the total estimated value is $€ 128,802$.

\section{e. Urban Water supply}

Urban water for the town of Zarnesti is provided entirely by PCNP. Using the average urban consumption in Romania (Rowaters, 2010) and the tariff of $€ 0.08$ per $\mathrm{m} 3$ paid to local water operator, the cost of water supply is evaluated at $€ 227,893$. It was assumed that these charges include fees paid to Rowaters (Romanian State Water Administration Company) plus the treatment and distribution costs and a gross profit of $10 \%$. Soil erosion regulating services are estimated at $€ 900$ in 2012.

\section{B. Distribution of $P A$ values}

Summing up all the benefits yields a total estimated value of $€ 13,472,202$ distributed among sectors (Fig. 1). The greatest part of this value is associated with tourism (80\%), followed by agriculture. Tourism revenues are undoubtedly a key value generated by PCNP, and their importance should be emphasized. At the same time, however, the most accurate and the largest amount of data available relate to tourism in comparison to other sectors (such as soil erosion regulation services, for which it has been impossible to fully value the wide range of economic impacts).

At the same time, the estimated ES values create benefits for a wide range of stakeholders groups. Thus $50 \%$ of the value accrues to non-commercial beneficiaries: mainly local communities and visitors. A significant share of this value represents consumer surplus that should and can be captured by the tourism sector, with a high potential benefit for local communities. Carbon trading is an opportunity that should be explored and can bring some benefits to private forest owners (Olofsson et al., 2011). A significant beneficiary of PCNP goods and services (49\%) is the private sector, mainly small-scale entrepreneurs in tourism, non-state forest owners and administrators. Public beneficiaries account for only $1 \%$ of the estimated TEV.

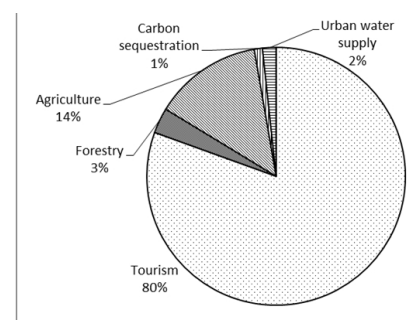

Fig. 1. Contribution of different sectors and activities to PCNP value

\section{Conclusions}

PCNP generates significant values and supports different sectors of the local economy, including tourism, water, agriculture, forestry and climate change mitigation. A very low economic effect is mirrored in the earnings of the PA administration and this translates into low cost recovery. In the tourism sector especially, many services are provided free of charge to users willing to pay for them, this being a potential market for PCNP management and owners of local touristic infrastructure.

\section{Acknowledgements}

Special thanks to the entire team involved in the GEFUNDP project "Improving the Financial Sustainability of the Carpathian System of Protected Areas", as the framework for financing the work of the team from Transilvania University of Brasov.

\section{References}

Abrudan IV (2012): A Decade of Non-State Administration of Forest in Romania: Achievements and Challenges. International Forestry Review 14(3):275-284.

Bann C, Popa B (2012). An Assessment of the Contribution of Ecosystems in Protected Areas to Sector Growth and Human Well Being in Romania. United Nations Development Programme, Bucuresti, $122 \mathrm{p}$.

Bateman I, Carson RT, Day B, Hanemann M, Hanley N, Hett T, Jones-Lee M, Loomes G, Mourato S, Ozdemiroglu E, Pearce DW, Sugden R, Swanson J (2002). Economic Valuation with Stated Preference Techniques: A Manual. Edward Elgar Publishing, Cheltenham, $480 \mathrm{p}$.

Birda A (2011). Financial Analysis of the Natural Protected Areas Targeted by the Project "Improving the Financial Sustainability of the Carpathian System of Protected Areas". United Nations Development Programme, Bucuresti, 25 p.

Bockstael NE, McConnell KE (2006). Environmental and Resource Valuation with Revealed Preferences: A Theoretical Guide to Empirical Models. Springer, London, 371 p.

Ceroni M (2007). Ecosystem Services and Local Economy in Maramures Mountains Natural Park, Romania. United Nations Development Programme, Bucuresti. 57 p.

Dumitras D, Dragoi S (2006). Estimation of the Recreation Values of Some Romanian Parks by Travel Cost Method. Buletin USAMV-CN 63.

Emerton L (2011). The Economic Value of Protected Areas in Montenegro. United Nations Development Programme, Podgorica, $31 \mathrm{p}$.

Forster DL, Bardos C, Southgate DD (1987). Soil Erosion and Water Treatment Costs. J Soil Water Conserv 42(2):349352.

Getzner M (2009). Economic and Cultural Values Related to Protected Areas. Part A: Valuation of Ecosystem Services in 
612

Tatra (PL) and Slovensky Raj (SK) National Parks. World Wide Fund for Nature Danube Carpathian Programme, Vienna.

Giurgiu V, Decei I, Armasescu S (1972). Biometria arborilor si arboretelor din Romania Ceres (Romanian Trees and Stands Biometrics), Bucuresti, 1155 p.

IGES - Institute for Global Environmental Strategies for IPCC (2006). Guidelines for National Greenhouse Gas Inventories (http://www.ipcc.ch/publications_and_data/).

INCDT - National Institute for Research and Development for Tourism (2009). Strategia nationala de dezvoltare a ecoturismului in Romania (National Strategy for Eco-Tourism Development in Romania), Ministry of Tourism and Regional Development, Bucuresti, $80 \mathrm{p}$.

Kanninen B J. (Ed.) (2007). Valuing Environmental Amenities Using Stated Choice Studies: A Common Sense Approach to Theory and Practice. Springer, London.

Leahu I (1994). Dendrometrie (Dendrometry). Editura didactica si pedagogica, Bucuresti, $374 \mathrm{p}$.

MARD - Romania. Ministry of Agriculture and Rural Development (2011). Technical Norms for Determining Pasturing Capacity. Romania. Ministerul Agriculturii si Dezvoltarii Rurale, Bucuresti.

MA (2005). Millennium Ecosystem Assessment. Ecosystems and Human Well-being. Island Press, Washington D.C. 137 p.

MO - Ministerial Order (2006). Ordin de ministru no. $625 / 2006$ privind aprobarea Metodologiei de calcul a sumelor cuvenite drept compensatii proprietarilor persoane fizice si juridice care detin paduri cu functii speciale de protectie (Ministerial Order for the Approval of the Establishing Methodology of Compensatory Amounts for Individuals and Legal Entities Owning Special Protection Forests). Monitorul Oficial al României, Partea I nr. 851.
Olofsson P, Kuemmerle T, Griffiths P, Knorn J, Baccini A, Gancz V, Blujdea V, Houghton RA, Abrudan IV, Woodcock CE (2011). Carbon Implications of Forest Restitution in Post-Socialist Romania. Environmental Research Letters 6(4):10 p.

PCNP (2008). Management Plan of Piatra Craiului National Park, Piatra Craiului National Park Administration, Zarnesti, $187 \mathrm{p}$.

Poynton S, Mitchell A, Ionascu G, McKinnenn F, Elliott J, Abrudan IV (2000). Economic Evaluation and Reform of the Romanian Forestry Sector. Editura "Pentru viata” Brasov, $138 \mathrm{p}$.

Rowaters - Romanian Waters (2010). Management Plan of Somes Tisa Water Basin. Romanian Waters Company, Bucuresti, $158 \mathrm{p}$.

Stancioiu PT, Abrudan IV, Dutca I (2010): The Natura 2000 Ecological Network and Forests in Romania: Implications on Management and Administration. International Forestry Review 12(1):106-113.

Taylor LO (2003). The Hedonic Method, p.331-394. In: Champ P, Brown T, Boyle K (Eds.). A Primer in Non-market Valuation. Kluwer Academic Publishers, Boston.

TEEB - The Economics of Ecosystems and Biodiversity (2010). Mainstreaming the Economics of Nature: A synthesis of the approach, conclusions and recommendations of TEEB. Progress Press, Malta, 39 p.

Terente M (2008). Modelarea si analiza digitala a terenului, cu aplicatii in bazinul montan al Teleajenului (Land Modelling and Digital Analysis, with Applications in the Teleajen River Mountain Drainage Basin). Universitatea Bucuresti, Facultatea de Geografie, Licence Work.

Ward FA, Beal DJ (2000). Valuing Nature with Travel Cost Models: A Manual. Edward Elgar Publishing, Cheltenham. 